\title{
Liver Cancer pT1 TNM Finding v6
}

National Cancer Institute

\section{Source}

National Cancer Institute. Liver Cancer pT1 TNM Finding v6. NCI Thesaurus. Code C61171.

Liver cancer with a solitary tumor of any size without vascular invasion. (from AJCC 6th Ed.) 